\title{
Flow Assurance Study on Offshore Marginal Oil Field Development in Vietnam: The Case of Ca Ngu Vang Oil Field
}

\author{
Van Thinh NGUYEN ${ }^{1, *}$, Thi Hai Yen NGUYEN ${ }^{1)}$, Tien Thang TRINH ${ }^{2)}$, \\ Canh Son TONG ${ }^{3)}$, Dinh Hoe LE
}

\footnotetext{
1) Faculty of Oil and Gas, Hanoi University of Mining and Geology (HUMG), Vietnam; email: nguyenvanthinh@humg.edu.vn; nguyenthihaiyen@humg.edu.vn

2) PetroVietnam Exploration Production Corporation (PVEP), Vietnam; email: thang.trinhtien@gmail.com

3) Russia-Vietnam Joint Venture (Vietsovpetro), Vietnam; email: sontc.rd@vietsov.com.vn; hoeld.rd@vietsov.com.vn
}

http://doi.org/10.29227/IM-2020-02-04

Submission date: 06-03-2020 | Review date: 22-09-2020

\begin{abstract}
Over the last few years, PetroVietnam has discovered and exploited several marginal oil fields such as Ca Ngu Vang, Te Giac Trang, Hai Su Den, Hai Su Trang, etc. however the reserves are modest. Test results received during drilling exploratory wells within these fields indicated that the maximum total daily production rate from the wells could promisingly range to about 20,000 barrels of oil per day (BOPD). Unfortunately, the optimum development of these offshore oil fields still offers numerous challenges to oil engineers due to the limitations of equipment and technology. Oil production activities worldwide show that if the daily production of an offshore oilfield is less than 20,000 BOPD, a connection of the marginal fields to their nearest larger oil field should be taken into consideration in order to efficaciously recover more crude oil. Often, this method of production requires a long subsea pipeline system. Besides, the transportation of the fluids from these fields to the processing platform will undergo several serious problems caused by the deposition of wax. All these matters should be handled to guarantee the performance of transportation. A number of models using PIPESIM, PIPEPHRASE and OLGA have been applied to design and examine the operations of the subsea pipeline in different working conditions. Results of the simulations proposed the use of passive insulation to economically eliminate wax deposition and recommended proper pipeline shutdown operations to minimize several problems related to flow assurance issues in the region of interest.
\end{abstract}

Keywords: marginal field, flow assurance, pipeline, Ca Ngu Vang

\section{Introduction}

Oil wells offer their maximum flow rates at the early stage of their life. Over time the production declines to correspond to the actual reserve of each individual field. Currently, most of the oil fields off the coast of Vietnam are going into their time of depletion. Thus, it is urgent to either search for new fields with profuse natural reserves or to develop marginal fields. In recent years, aiming at reducing of operation and production expenses, PetroVietnam (PVN) has been concentrating on exploiting the marginal oil fields such as $\mathrm{Ca} \mathrm{Ngu}$ Vang, Te Giac Trang, Dong Do, Hai Su Den, Hai Su Trang, etc. in spite of their limited quantities. Encouraging results primarily gained from this approach elucidated that the most effective method to economically develop new satellite wells is to use their current costly infrastructure (Phung Dinh Thuc et al., 2016). However, the transportation of crude oil within these fields through pipeline faces a number of difficulties related to the properties of production fluid, the temperature of seawater at the place of interest, the technical features of the pipe and also the operation of the system, etc. Strictly obeying all procedures in "flow assurance" is a must to make sure about the efficiency of the production activities.

Vastly applicable from the very beginning at production wellheads to the retailers or end-users, pipeline transportation systems have been increasingly recognised as a critical factor of the production process, from the conceptual study phase through to the project operational phase. During the transportation by this method, flow assurance is considered as a system engineering approach to maximise the performance of the whole transporting network in use (Marcia Cristina Khalil de Oliveira et al., 2014; Gupta et al., 2015). Issues related to this activity are extremely diverse, encompassing many specialised subjects and covering a full range of technical disciplines. Therefore, implementation of relevant design practices pertains to successful field development across all aspects of the design process.

- As a matter of fact, in recent years, flow assurance has been of great attention and thus is broadening to include a multiplicity of other issues which can affect the production of oil and gas, thanks to its popularity. Consequently, the term "flow assurance" once defined by Petrobras in the 1990s now characterises a larger range of matters including:

- A steady-state analysis which considers the calculation of pressure drop and temperature variation versus production rate, pipeline size, and insulation options.

- Production chemistry deals with problems related to hydrates, waxes, asphaltenes, scaling and corrosivity, etc.

- Operability characteristics or transient analysis, which monitor system start-up and restart, slugging potential, pipeline shutdown and cool down.

In this paper, we concentrate on establishing a pipeline system which is technically and economically affordable to transport crude oil from the marginal field of Ca Ngu Vang 


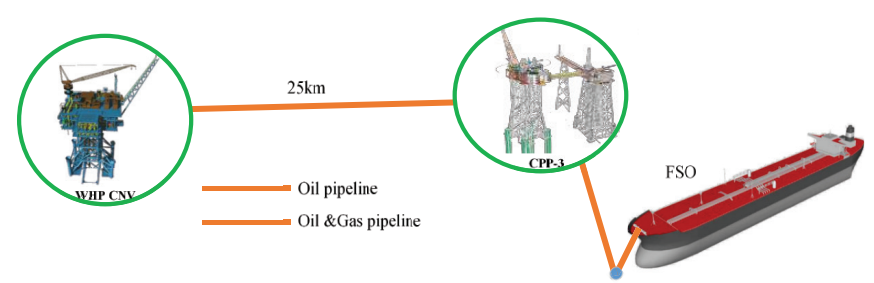

Fig. 1. The transportation pipeline from Ca Ngu Vang to CPP-3 Bach Ho oil field Rys. 1. Rurociąg transportowy z Ca Ngu Vang do pola naftowego CPP-3 Bach Ho

Tab. 1. Physical properties of crude oil at CNV oil field

Tab. 1. Właściwości fizyczne ropy naftowej na polu CNV

\begin{tabular}{|l|l|l|}
\hline \multicolumn{1}{|c|}{ Parameters } & \multicolumn{1}{c|}{ Units } & \multicolumn{1}{c|}{ Value } \\
\hline Density & $\mathrm{kg} / \mathrm{m}^{3}$ & $804-809$ \\
\hline Wax appearance temperature (WAT) & ${ }^{\circ} \mathrm{C}$ & 36 \\
\hline Gel point & ${ }^{\circ} \mathrm{C}$ & 64 \\
\hline Dynamic viscosity at $37.8^{\circ} \mathrm{C}$ & $\mathrm{mPa} . \mathrm{s}$ & 9.8 \\
\hline Dynamic viscosity at $50^{\circ} \mathrm{C}$ & $\mathrm{mPa} . \mathrm{s}$ & 5.94 \\
\hline
\end{tabular}

(CNV) to CPP-3 platform, Bach Ho oil field. The transportation diagram is described in the figure above (fig.1). The CNV oil field, discovered in September 2002, is located in Block 9-2, about $17 \mathrm{~km}$ northeast of the nearest Bach Ho facility, 15 $\mathrm{km}$ southwest of the Rang Dong oil field and in approximately 60 meters of water depth. The oil and gas well stream fluids from CNV WHP (wellhead platform) will be transported to the CPP-3 platform via an insulated production pipeline for processing and onward transporting to an FSO tanker (oil) or to Dinh Co gas terminal. The length of the pipeline CNV WHP to CPP-3 is $25 \mathrm{~km}$.

Both steady-state and transient analysis are considered in our study. During the initial design phases of a subsea pipeline system, flow assurance is crucial in identifying the optimum pipeline parameters in the transportation network from the wellhead platform to the processing facilities. At this early stage, steady-state design methods are employed to ensure optimising pipeline mechanical, process and thermal design. In order to simulate multiphase pipelines and riser systems, PIPESIM and PIPEPHASE standard packages, highly compatible with steady-state analysis, are commonly applied. Multiphase flow in a pipeline, especially for initial start-up, shutdown and cool-down periods is an important dynamic phenomenon which required tremendous efforts to be fully characterised. Numerous approaches have been presented earlier to solve this problem. Of which, OLGA, supported by the petroleum industry worldwide, is a remarkably competent and reliable medium to deal with the transient flow in a pipeline. The dynamics during these processes, as well as the final conditions in the pipe, can be studied by transient simulation.

\section{Steady-State Analysis for CNV oilfield}

We demonstrate firstly on the pipeline sizing for CNV oil field at a design flow rate of 20,000 STB/D (the water cut is $0 \%$ and the GOR is $2754 \mathrm{scf} / \mathrm{STB}$ ). The components and properties of the crude are shown in table 1 (Phung Dinh Thuc et al., 2016).

The production pipeline routes from CNV WHP to CPP-3 consist of two vertical risers, and one horizontal pipeline. The water depth along the pipeline varies from $55.5 \mathrm{~m}$ at the CNV WHP to $46.0 \mathrm{~m}$ at the CPP-3 platform. Generally speaking, the seabed is relatively flat with a gradual downward slope in the northeast direction towards the CNV WHP. When determining pipeline size, the maximum flow rate expected during the life of the field should be considered rather than the initial flow rate. Usually, it is advisable to add a surge factor of about $20 \%$ to $50 \%$ (Gary Grove et al., 2008) to the anticipated normal flow rate, unless surge expectations are more precisely determined or simulated. The initial pipeline sizing is commenced with the calculation of the inlet pressure at WHP. The steady outlet pressure is chosen at the processing platform.

Figure 3 displays the relation between sizes of pipelines and pressure at the wellhead where curves in different colours indicate different inner diameters of the flow lines tested. It can be seen from this figure that a 9-inch $(228.6 \mathrm{~mm})$ inner diameter flowline is sufficient to transport the peak flow rate of $20,000 \mathrm{STB} / \mathrm{d}$ at the lowest available producing wellhead pressure of 11.4 MPa. However, for the sake of safety, a normal 10" (232.3 mm ID) diameter pipe was empirically chosen for this pipeline system to transport crude from CNV WHP to CPP-3 platform, Bach Ho oil field.

\section{Determination of the thermal insulation properties for subsea pipelines}

Based on the laboratory data obtained from the production fluids, the subsea development is assumed to confront significant wax deposition and gel formation challenges (Tong Canh Son et al., 2015). From a flow assurance perspective, the objective, therefore, is to utilise all the available laboratory measurements to determine the operational strategies to alleviate wax deposition and/or gel formation during all steadystate and transient events.

The crude oil produced on CNV oil field containing a high percentage of wax has been tested to have a pour point of $36^{\circ} \mathrm{C}$, and the minimum seawater temperature surrounding the production pipeline is expected to be around $22^{\circ} \mathrm{C}$ (Tong Canh Son et al., 2015). This raises oil gelling concerns, especially during extended shutdowns. Variation in temperature is the dominant factor affecting the waxy crude oil properties. Below a certain temperature which is called the wax appearance temperature (WAT), the wax crystallises out of the liquid solution. The precipitation of the wax components out of the oil is responsible for the changes in the waxy crude oil properties, including the gelling of the oil and an increase in vis- 


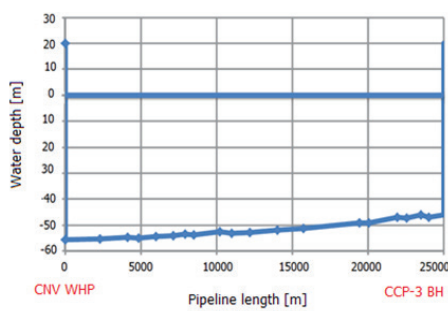

Fig. 2. CNV WHP to CPP-3 pipeline profile Rys. 2. Profil rurociągu CNV WHP do CPP-3

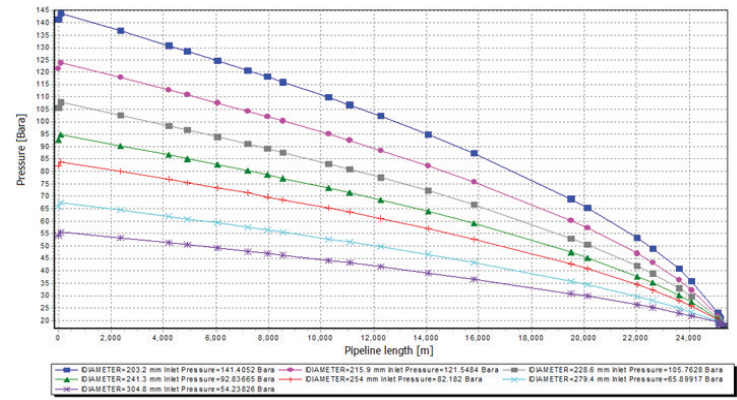

Fig. 3. Flowline inlet pressure at CNV with a flow rate of $20,000 \mathrm{STB} / \mathrm{d}$ vs pipe sizes Rys. 3. Ciśnienie wlotowe przepływu przy CNV z przepływem 20000 STB /d w stosunku do rozmiarów rur

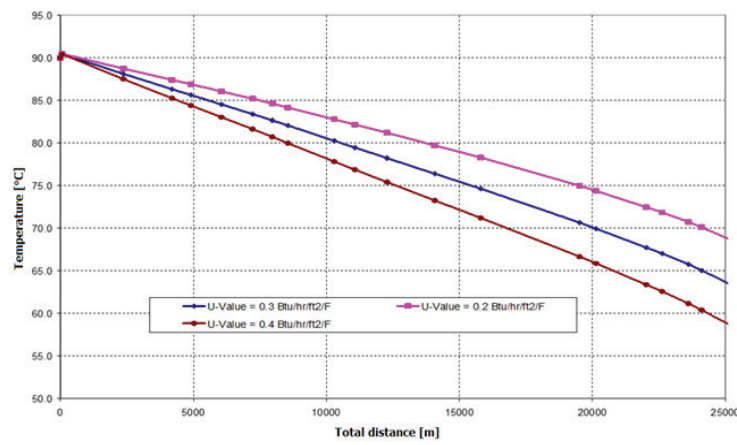

Fig. 4. The temperature profile of the CNV WHP->CPP-3 pipeline with a flowrate of 20,000 STB/d vs U-Values Rys. 4. Profil temperaturowy rurociągu CNV WHP-> CPP-3 o przepływie 20000 STB / d względem wartości U

cosity. When the fluid temperature falls below the WAT, there is the possibility of wax deposition on the pipelines. Therefore, if the oil is transported at a temperature below $64^{\circ} \mathrm{C}$, wax deposition can occur in the pipeline. The wax deposition will reduce the effective flow volume and may lead to complete pipeline blockage (Ararimeh Aiyejina et al., 2011; Zahra Jeirani et al., 2007).

Because the CNV fluid Wax Appearance Temperature (WAT) is $64^{\circ} \mathrm{C}$, the primary flow assurance risk associated with steady-state production of this field is wax deposition. Wax deposition in the subsea system can be prevented by using either of the two following options: Passive insulation and Active heating.

Passive insulation was determined to be the most economical method to avoid a wax deposition. Therefore, it was necessary to insulate the subsea tieback with PU foam insulation with nominal thermal transmittance or U-value (U-factor) of $0.2,0.3$ and $0.4 \mathrm{BTU} / \mathrm{ft} 2 \mathrm{hr}^{\circ} \mathrm{F}$.

To select the $U$-value of the insulation required, the steady-state thermal-hydraulic calculation of the flowline CNV WHP ->CPP-3 was performed by PIPESIME. Three models were run with three different $\mathrm{U}$-values of $0.2,0.3$ and
0.4 respectively. The flow rate utilised in the models was the maximum value $20,000 \mathrm{STB} / \mathrm{d}$. The calculation results are presented in the diagram below (fig. 4).

As described in the figure, temperatures of the fluid transported received the same value of around $90^{\circ} \mathrm{C}$ at the inlet of the three transportation pipelines corresponding to three selected thermal transmittances. Obviously, a significant decrease in temperature could be observed throughout the transportation route of $25 \mathrm{~km}$ in all three cases. However, one insulated with $\mathrm{U}$-values of 0.4 has a temperature drop of around $35 \%$ which means that the temperature at the end of the flowline declines to below $64^{\circ} \mathrm{C}$. The other systems (U-value of 0.2 and 0.3 ) in turn pose approximately $29 \%$ and $24 \%$ reductions. On the other hand, temperatures at the terminals all reach above $64^{\circ} \mathrm{C}$, above the Wax Appearance Temperature (WAT) of the crude oil at CNV field and thus the precipitation of waxy fluids or the deposition of wax could be eliminated (Zahra Jeirani at el, 2007). However simulation result indicates that an insulation layer with $\mathrm{U}$-value of $0.2 \mathrm{BTU} / \mathrm{ft} 2 \mathrm{hr}{ }^{\circ} \mathrm{F}$ is ideal for maintaining the temperature of the transported product above the WAT at a flow rate of 20,000 STB/d, the expense is still an important factor should be considered. Based 
Tab. 3. Effect of saturation pressure on rheology crude oil at Bach Ho oil field

Tab. 3. Wpływ ciśnienia nasycenia na reologię ropy naftowej na złożu Bach Ho

\begin{tabular}{|c|c|c|c|c|c|}
\hline \multirow{3}{*}{$\begin{array}{c}\text { Temperature } \\
{\left[{ }^{\circ} \mathbf{C}\right]}\end{array}$} & \multicolumn{6}{|c|}{ Pressure [atm] } \\
\cline { 2 - 6 } & \multicolumn{7}{|c|}{ Plastic viscosity [mPas] } \\
\hline 22 & 105 & 82 & 69 & 51 & 40 \\
\hline 26 & 60 & 46 & 41 & 32 & 27 \\
\hline 28 & 41 & 32 & 28 & 24 & 20 \\
\hline 30 & 28 & 23 & 21 & 17 & 15 \\
\hline 35 & 18 & 16 & 14 & 13 & 11 \\
\hline
\end{tabular}

on experience, for the sake of safety and cost, the U-value of $0.241 \mathrm{BTU} / \mathrm{ft} 2 \mathrm{hr}^{\circ} \mathrm{F}$ was empirically chosen to insulate the pipeline system CNV - CPP-3 in this research.

\section{Transient Multiphase Modelling \\ Pipeline Initial Start-up Simulation}

After the construction completed, hydraulic tests (hydrostatic test) are required to investigate the tightness and ensure the proper performance of the pipeline system. Normally, water is chosen as a standard hydrotest fluid. In most cases, the fluid will be treated in advance with some adequate chemical materials including oxygen absorbers in order to reduce or wipe out the oxygen content in the pipework, corrosion inhibitors to inhibit popular corrosion forms occurring during the transport, biocides to minimise the appearance and development of bacteria within the tubular space (Rupi Prasad, 2003). During the hydrotest procedure, the pipeline will be fulfilled with hydrotest liquid at ambient temperature. As the pipeline is $25 \mathrm{~km}$ long, it is assumed to take a significant period of time for the fluid to reach the steady-state. Theoretically, the viscosity of a liquid decreases dependably with the increase of temperature. The viscosity of the crude at Bach Ho oil field was recorded to drop remarkably at the temperature from $30^{\circ} \mathrm{C}$ to $40^{\circ} \mathrm{C}$ (see table 3) (Nguyen Thuc Khang et al., 1999). Thus, the long thermal transients in insulated pipelines mean that it can take several days to reach the steady-state flow regime.

For the season that the purity of the production fluid should be preserved when the system officially runs, and it is mandatory to discharge the remaining test fluid out of the system in the strict consideration of the environment. This procedure will be simulated in the initial start-up process using OLGA software. The pipeline system from CNV WHP to CPP-3 platform, with the same technical specifications as presented in the previous parts of this article, was investigated in the case the production rate reached to about $6000 \mathrm{BOPD}$.

Results displayed in figure 5 show the replacement of hydrostatic testing fluid by the initial well stream where the vertical axis corresponds to the water fraction or water cut within the pipeline and the horizontal axis represents the length of the transport system. Despite the simplicity of the model, its simulation results present interesting and surprising transient behaviour. As noticed in the figure, the first trail of hydrocarbon crude (mostly gas) reaches the CPP-3 riser after approximately 100 minutes. Ten hours after introducing the good streams to the pipeline, the hydrotest water from the pipeline is completely removed.

Figure 6 characterises the oil fraction when the initial fluid flows inside the pipeline after $0.5 \mathrm{~h}, 1 \mathrm{~h}, 1.5 \mathrm{~h}, 2 \mathrm{~h}, 2.5 \mathrm{~h}, 3 \mathrm{~h}$,
$3.5 \mathrm{~h} . . .10 \mathrm{~h}$ in case the exploitation flowrate at the wellhead platform was 6000 BOPD. Results gained from numerical models remark the first gas flux to come to the riser CPP-3 after about $1.5 \mathrm{~h}$. A high water fraction inside the pipe was still displayed after the oil stream was pumped in about 3 hours. This is comprehensible due to a portion of hydrotest liquid remained. The first oil flow to reach the CPP-3 riser could be observed after approximately 3.5 hours and 10 hours after operating the system, water residing in the pipe was completely replaced by oil and gas mixture.

Figure 7 denotes the variation of oil temperature in the pipeline in the initial start-up period. In this case, during the displacement of water by the exploited crude, the temperature of the flowline increased while the temperature of the product inside the riser CPP-3 began to decrease as the result of the gas separation and then raised up again. From 20 to 60 hours later, both the wells and the pipeline system increase in temperature thanks to the increase in temperature of the production well. Consequently, the temperature of the transported fluid in the pipeline soon reaches its stable value or the flow soon becomes a steady flow at approximately 60 hours after the hydrocarbons are introduced to the system. When the transportation continued at a stable flow rate of 6000 BODP, if the pressure at the CPP-3 riser was set up at 18 bara, the pressure at the CNV WHP would be 32.3 bara (fig. 8 ).

\section{Pipeline Shutdown Simulation}

In the case of a prolonged shutdown, the convey stops, the fluid in the pipeline cools down results in the crystallisation of the waxy components of the crude oil. The crystallisation of wax may consequently form gel-like accumulations along with the piping system and thus increase the critical restart pressure to restart the conveying, which lead to the necessity of recalculating this parameter. To predict the necessary restart pressure for the shutdown pipeline imposing a potential risk of being frozen, the volume of the liquid in the pipeline and the corresponding mechanical behaviour of the gelled oil must be assessed.

A shutdown state may be achieved in three ways: (1) By simultaneously closing the boarding valves at CNV and CPP3 , letting the flowline reach the settling pressure; (2) Closing only the boarding valve at CPP-3 resulting in packing the flowline; (3) closing only the boarding valve at CNV allowing the flowline to adjust to the CPP-3 arrival pressure.

For the pipeline path from CNV WHP to CPP-3 platform, the shutdown simulations were run as restarts from the steady-state case. Each above-mentioned scenario was run for six days to allow the fluids in the flowline to reach ambient temperature. At shutdown, the fluids were separate due to 


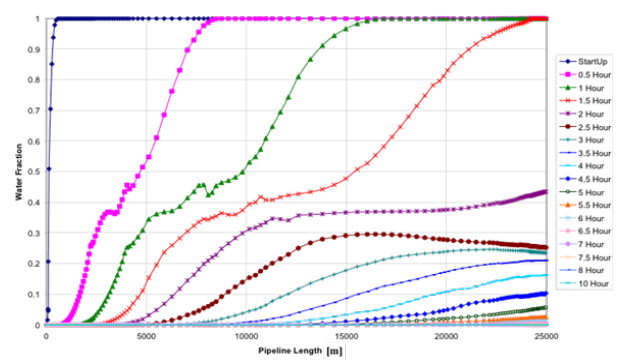

Fig. 5. Hydrotest water in the pipeline is replaced by well stream production in the initial start-up period Rys. 5. W początkowym okresie rozruchu woda hydrotestowa w rurociągu jest zastępowana przez wydobycie ze studni

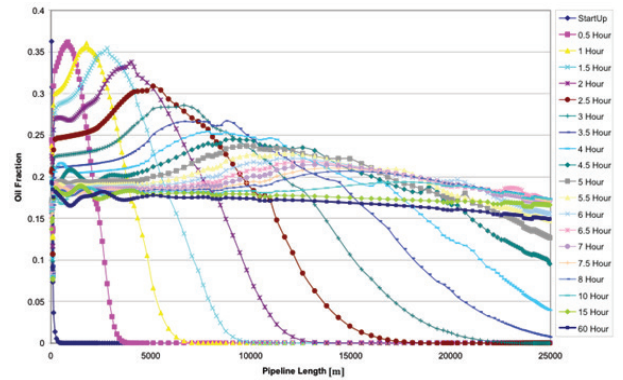

Fig. 6. Oil volume fraction in the pipeline initial start-up period Rys. 6. Udział objętościowy ropy w początkowym okresie rozruchu rurociągu

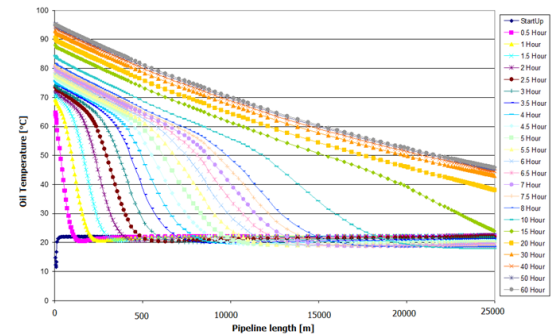

Fig.7. Oil temperature in the pipeline - initial start-up period Rys.7. Temperatura ropy w rurociągu - początkowy okres rozruchu

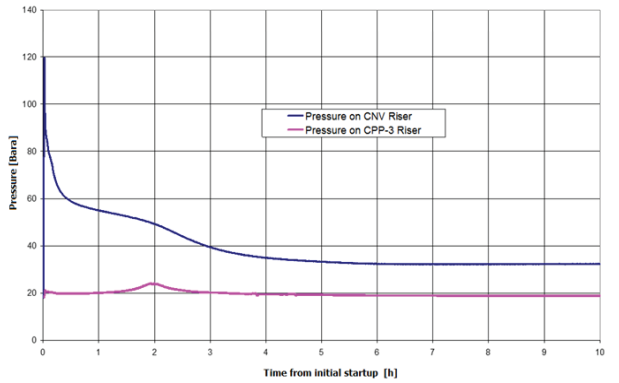

Fig. 8. Pressure at the top of CNV and CPP-3 Riser in initial start-up period Rys. 8. Ciśnienie w górnej części pionów CNV i CPP-3 w początkowym okresie rozruchu

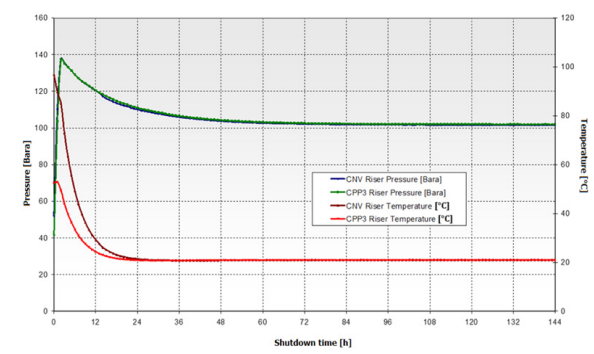

Fig. 9. Riser absolute pressure and temperature at CNV WHP and CPP-3 vs shutdown time Rys. 9. Ciśnienie bezwzględne i temperatura w pionie przy CNV WHP i CPP-3 w przypadku wyłączenia czasu 


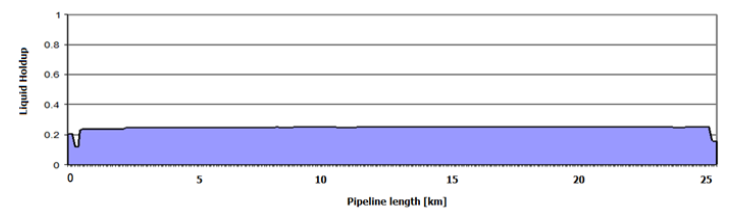

Fig. 10. Liquid holdup at steady-state flow with a flow rate of 6000 BOPD (before shutting) Rys. 10. Zatrzymanie cieczy przy przepływie w stanie ustalonym z natężeniem przepływu 6000 BOPD (przed zamknięciem)

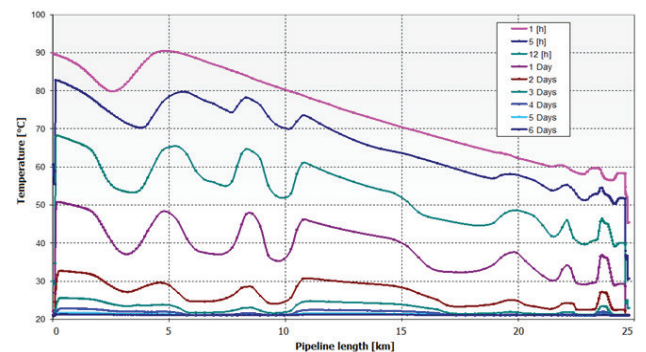

Fig. 11. Production temperature along the CNV WHP->CPP-3 pipeline at shutdown period Rys. 11. Temperatura produkcji wzdłuż rurociągu CNV WHP-> CPP-3 w okresie postoju

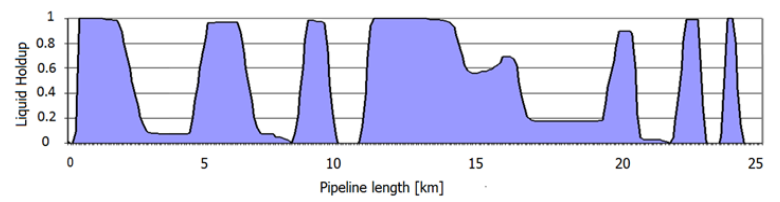

Fig. 12. Liquid holdup in the pipeline after 6 hours shutting Rys.12. Zatrzymanie cieczy w rurociągu po 6 godzinach od zamknięcia

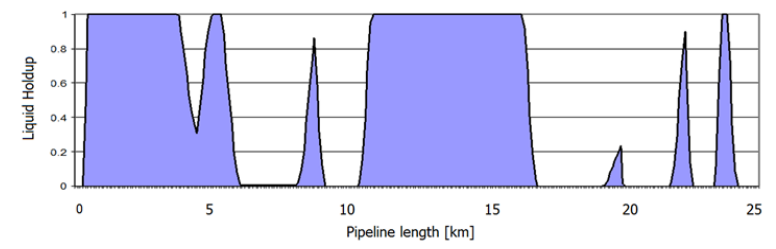

Fig. 13. Liquid holdup in the pipeline after 6 days shutting Rys. 13. Zatrzymanie cieczy w rurociągu po 6 dniach od zamknięcia

gravity, and the liquids flowed downhill towards CNV WHP terminal. As a matter of fact, because of the appearance of small humps on the seabed, the layout of pipeline throughout, or the path of conveyed fluid, is hardly horizontally or vertically linear. Consequently, liquids may be trapped somehow, somewhere on the route until they spill over to a lower side. Moreover, since oil or water cools down more slowly than gas, the fluid temperature is expected to be higher near the CNV riser, because of the higher initial temperature during flowing conditions and the higher liquid holdup at this point.

The shutdown simulation was accomplished based on the ditto pipeline transporting well stream fluid from the CNV WHP to $\mathrm{CPP}-3$ production platform with an unchanged production rate of 6000 BOPD. The shutdown was achieved by closing only the boarding valve at CPP- 3 terminal resulting in packing the flowline up to a pressure of 139 bars at CNV WHP (the third of the three aforementioned methods to shut the transporting system down). The simulation results are presented below.

In figure 9, the vertical axis on the left illustrates absolute pressure values, in Bara, at the risers, whereas the ver- tical axis on the thermal display of the transported fluid, ${ }^{\circ} \mathrm{C}$. The total shut down time tested was $144 \mathrm{~h}$, shown by the horizontal axis. Different colours distinguish temperatures and pressures at the two risers. At the beginning of the shutdown, the pressure at $\mathrm{CNV}$ riser increased from about 60 bara to 135 bara after 6 hours. The pressure in the pipeline then decreased and reached its stable value of around 80 bara after 60 hours, which is far higher than that of the steady-state. This value supposes to be a predicament considering the restart of the system. Besides, it is plain to observe in the figure that temperature drops dramatically from about $130^{\circ} \mathrm{C}$ at $\mathrm{CNV}$ riser and $70^{\circ} \mathrm{C}$ at $\mathrm{CPP}-3$ riser to $22^{\circ} \mathrm{C}$ corresponding to the shutdown time from 0 to $25 \mathrm{~h}$. Later on, the temperature at these two pipes remains stable at $22^{\circ} \mathrm{C}$ when shutdown time is lengthened furthermore, more than $140 \mathrm{~h}$ in the simulations. The results are quite reliable compared to experimental conclusions introduced by Mei Yang et al. (2011). Both indicate an extreme risk of wax formation to occur if the transportation in the system is by any mean stops working for more than 20h. In order to clarify this presumption, other calculations 
were run to clarify the liquid holdup fraction inside the pipe during the shutdown. Because being defined as a proportion of liquid contained in a multiphase transporting pipeline at particular flow conditions, the liquid holdup is considered as an essential factor to examine the appearance of slugs and consequently the operability of a pipeline.

Figure 10 presents the holdup in the pipeline at the steady-state before the shutdown. Here, the holdup of the transported fluid is distributed evenly along the flowline, and there is no observation of slugs. Figure 11 describes the temperature of the crude corresponding to the shutdown time of 1h, $5 \mathrm{~h}$ to 6 days. Apparently, the longer the shutdown time, the higher the temperature drop. Therefore, the formation of the holdup is inevitable. Figure 12 and 13 exhibit the distribution of the conveying fluid in the pipeline after six hours and six days, respectively. The holdup phenomenon is obviously shown in these two cases. However, the holdup is no longer concurrent compared to the steady-state. Under the action of gravity, the fluid accumulated, slugs appeared and resided longer at low positions of the pipeline profile, which obey the elevation of the seabed, throughout the system. Moreover, liquid holdup tends to increase when the viscosity of the fluid increases while this value depends on temperature.

\section{Conclusion}

It is evident that during extended shutdowns, the CNV oil thermodynamic conditions in the pipeline will cross the gelling envelope at a seabed temperature of $22{ }^{\circ} \mathrm{C}$. Hence, the $\mathrm{CNV}$ oil has the potential to gel in the pipeline at some time during production operations if the facilities shut down for an extended time. With the shutdown time from 6 hours to 6 days or more, liquid holdup calculating results proved the formation of slugs along the pipeline, which may subsequently afflict the transportation. Moreover, the temperature of the flowline decreases dramatically with the increase of shutdown time, and thus increases the restart pressure. If the system stops working for more than $20 \mathrm{~h}$, temperature varies from about $70^{\circ} \mathrm{C}$ to below $30^{\circ} \mathrm{C}$ whereas it is compulsory to keep the temperature of the pipeline system from more than $64^{\circ} \mathrm{C}$ (gel point) to more than $36^{\circ} \mathrm{C}$ (Wax point) for the pipeline $\mathrm{CNV}->\mathrm{CPP}-3$. Therefore, the shutdown time, in any case, should not exceed this threshold in order to get rid of the risks of relevant pressure and temperature when restarting the transport system.

\section{Acknowledgement}

The authors are grateful for Vietsovpetro's support to provide invaluable information and appreciate their cooperation and exchange of simulation data. 


\section{Literatura - References}

1. Nguyen Thuc Khang, Ha Van Bich, Tong Canh Son, Basement of White Tiger and Dragon Oilfields. PetroVietnam Journal. 1999. (in Vietnamese).

2. Tong Canh Son, Le Dinh Hoe. Experience of high waxy crude transportation through a submarine pipeline in "Vietsovpetro" offshore oil fields. PetroVietnam Journal. 2015, p. 43-52. (in Vietnamese).

3. Phung Dinh Thuc, Tong Canh Son, Le Dinh Hoe, Ngo Huu Hai. The Tie-in of Ca Ngu Vang to Bach Ho oil field and experience of marginal oil fields tie-in with existing large oil filed. PetroVietnam Journal. 2016, p. 28-32. (in Vietnamese).

4. ARARIMEH AIYEJINA, DHURJATI PRASAD, CHAKRABARTI, ANGELUS PILGRIM, M.K.S.SASTRY. Wax formation in oil pipelines: A critical review. International journal of multiphase flow. 2011, Vol. 37, Issue 7. p. 671-694.

5. GUPTA, ANAND \& SIRCAR, ANIRBID \& PDPU, INDIA. Need for Flow Assurance for Crude Oil Pipelines: A Review. International Journal of Computational Science and Engineering. 2015, Vol.6, p. 43-49. ISN 2015-2045.

6. GARY GROVE, GEIR SAETHER AND GIOVANNI P. ESTRADA. Employing Flow Assurance in an Offshore FEED Study. SPE 116254, p. 1-10.

7. MARCIA CRISTINA KHALIL DE OLIVEIRA, ADRIANA TEIXEIRA, LENISE COUTO VIEIRA, ROBERTOR DE FONSECA JUNOR. Flow assurance challenges for long subsea pipelines. Rio Oil \& Gas Expo and Conference 2014.

8. MEI YANG, JAQIANG JING, LINGLIN LEI, JIATONG TAN. Simulation Testing on the Shutdown and Safe Restart of Crude Oil Pipelines. International Conference on pipelines and trenchless technology. October 2011, p 14541464 .

9. RUPI PRASAD. Chemical treatment options for hydrotest water to control corrosion and bacterial growth. Corrosion 2003, NACE -03572, NACE International, San Dieogo, California, 2003.

10. ZAHRA JEIRANI, ASGHAR LASHANIADEGAN, SHAHAB AYATOLLAHI, J. JAVANMARDI. The Possibility of Wax Formation in Gas Fields: a Case Study. Journal of Natural gas chemistry. 2007, p. 293-300.

Badanie zapewnienia rozwoju przepływu w przybrzeżnych marginalnych pól naftowych $w$ Wietnamie: Studium przypadku pola naftowego Ca Ngu Vang

W ciagu ostatnich kilku lat $w$ Vietnamie odkryto i eksploatowano kilka marginalnych pól naftowych, takich jak Ca Ngu Vang, Te Giac Trang, Hai Su Den, Hai Su Trang, itd.... Jednak zasoby sa skromne. Wyniki testów otrzymane podczas wiercenia odwiertów poszukiwawczych na tych polach wykazały, że maksymalny całkowity dzienny poziom wydobycia z odwiertów może potencjalnie sięgać około 20000 baryłek ropy dziennie (BOPD). Niestety, optymalny rozwój tych przybrzeżnych pól naftowych nadal stwarza liczne wyzwania dla inżynierów naftowych ze względu na ograniczenia sprzętu i technologii. Działalność wydobywcza ropy naftowej na calym świecie pokazuje, że jeśli dzienna produkcja morskiego pola naftowego jest mniejsza niż 20000 BOPD, należy wzią́ pod uwage połaczenie pól marginalnych $z$ ich najbliższym większym polem naftowym, aby efektywnie odzyskać więcej ropy. Często ta metoda produkcji wymaga dlugiego systemu rurociagów podmorskich. Poza tym transport płynów z tych pól na platformę obróbkowa będzie wiązał się z kilkoma poważnymi problemami spowodowanymi osadzaniem się wosku. Wszystkie te sprawy powinny być załatwione, aby zagwarantować wykonanie transportu. Szereg modeli wykorzystujących PIPESIM, PIPEPHRASE i OLGA zostało zastosowanych do projektowania i badania działania rurociągu podmorskiego w różnych warunkach pracy. W wynikach symulacji zaproponowano zastosowanie izolacji pasywnej w celu ekonomicznego wyeliminowania osadzania się wosku oraz zalecono prawidłowe operacje wyłaczania rurociagu, aby zminimalizować kilka problemów związanych $z$ kwestiami zapewnienia przepływu w obszarze zainteresowania.

Słowa kluczowe: pole marginalne, zapewnienie przeplywu, rurociag, Ca Ngu Vang 